\title{
Seasonal Ecophysiology of an Endangered Coastal Species, the Yellow-horned Poppy (Glaucium flavum Crantz) ${ }^{1}$
}

\author{
J. Cambrollé, S. Redondo-Gómez, E. Mateos-Naranjo, T. Luque, and M. E. Figueroa \\ Departamento de Biología Vegetal y Ecología, Facultad de Biología, Universidad de Sevilla, \\ Apartado 1095, 41080 Sevilla, España \\ e-mail: cambrolle@us.es \\ Received August 10, 2011
}

\begin{abstract}
Glaucium flavum Crantz. is a short-lived perennial herb distributed in coastal zones from the Black Sea to southern, western and north-western Europe. Despite its diminishing area of distribution and potential pharmacological value, little is known about the ecophysiological features of this coastal species. We investigated the photosynthetic performance of G. flavum by measuring gas exchange, chlorophyll fluorescence, photosynthetic pigment concentration and leaf water content over the space of a year in a coastal habitat of SW Spain. We also measured the variation in total concentrations of nitrogen, phosphorus, sulphur, potassium, calcium and magnesium, in the leaves and soil, throughout the study period. G. flavum showed a high resistance to summer drought conditions which appeared to be due to the high degree of stomatal control. The potential photochemical efficiency of photosystem II showed minimum values during the winter, indicating that low temperatures can produce negative effects within the photosynthetic apparatus. However, the marked decline in net photosynthesis during the winter seems to be mainly related to a loss of metabolic activity. Although leaf nutrient concentrations were, in general, within the normal ranges, phosphorus availability seems to be limited by the high calcium concentrations detected in the soil of the study site. Our study points out the efficiency of the different physiological adaptations of this rare and endangered coastal species in coping with the strong seasonal variability of the Mediterranean climate.
\end{abstract}

Keywords: ecophysiology, coastal flora, Glaucium flavum, photosynthesis, nutrients

DOI: $10.1134 / \mathrm{S} 1067413614030023$

\section{INTRODUCTION}

The yellow horned poppy, Glaucium flavum Crantz., is a short-lived latex-bearing perennial herb. It is found mainly in calcareous soils on sand dunes, cliffs and shingle beaches from the Black Sea through southern and western to north-western Europe (Scott, 1963). Like many other plants of the family Papaveraceae, G. flavum contains benzyl-isoquinoline alkaloids, some of which have therapeutic properties (Kintsurashvili and Vachnadze, 2000). At present, G. flavum is included in various IUCN categories in certain parts of its distribution area (e.g. 'Critically Endangered' in Norway and 'Endangered' in Romania), and several authors have reported the retreat of its populations in many parts of Europe (e.g. Rappé, 1984; Prieto et al., 2007; Solås et al., 2007).

\footnotetext{
${ }^{1}$ The article is published in the original.

Abbreviations: A, net photosynthetic rate; Chl $a+b$, chlorophyll $a$ and chlorophyll $b ; \mathrm{Ci}$, intercellular $\mathrm{CO}_{2}$ concentration; $\mathrm{Cx}+c$, carotenoids; $\mathrm{F}_{0}$, minimal fluorescence level in the dark-adapted state; $\mathrm{F}_{\mathrm{m}}$, maximal fluorescence level in the dark-adapted state; $F_{\mathrm{s}}$, steady state fluorescence yield; $F_{v}$, variable fluorescence level in the dark-adapted state; $\mathrm{F}_{\mathrm{v}} / \mathrm{F}_{\mathrm{m}}$, maximum quantum efficiency of PSII photochemistry; ФPSII, quantum efficiency of PSII; Gs, stomatal conductance; LWC, leaf water content; NPQ, non-photochemical quenching; RGR, relative growth rate.
}

In most of its distribution area, G. flavum is subject to the strong seasonal effects of the Mediterranean climate. This climate offers contrasting challenges for plant growth that oscillate between hot, arid summers with high irradiance and cool winters with irregular rainfall and episodic frosts (Figueroa et al., 1997). The flora of coastal dunes, shingle and rocky beaches are also exposed to other adverse physical conditions, such as the influence of salt-spray, lack of fresh water and/or nutrient scarcity (Packham and Willis, 1997). Although recent studies under greenhouse conditions have indicated the high tolerance of G. flavum to certain potential stress factors (Cambrollé et al., 2011a, b), little is known about the ecophysiology of this coastal species in its natural habitat. The clear lack of information about the effects of environmental conditions on the performance of $G$. flavum and the cited reduction of its distribution area highlight the need to expand the knowledge about this Mediterranean coastal species.

The aim of this work was to describe the ecophysiological features of $G$. flavum under natural conditions. For this purpose, levels of gaseous exchange, chlorophyll fluorescence, photosynthetic pigments, leaf water content, and both foliar and soil concentrations of nitrogen, phosphorus, sulphur, potassium, 
Physicochemical properties of soil at the study site. Values represent mean $\pm \mathrm{SE}, n=5$

\begin{tabular}{l|c}
\hline \multicolumn{1}{c|}{ Parameter } & Soil \\
\hline Gravel, $\%$ & $38 \pm 6$ \\
Medium and coarse sand, $\%$ & $62 \pm 8$ \\
Fine sand, silt and clay, $\%$ & $4 \pm 2$ \\
pH & $8.4 \pm 0.03$ \\
Conductivity, $\mathrm{mS} \mathrm{cm}^{-1}$ & $0.16 \pm 0.02$ \\
\hline
\end{tabular}

calcium and magnesium were assessed monthly over the course of a year in a typical coastal habitat of SW Spain.

\section{MATERIAL AND METHODS}

\section{Study Area and Sampling Procedures}

The study was conducted in the joint estuary of the Odiel and Tinto rivers in Huelva, on the Atlantic coast of SW Spain $\left(37^{\circ} 15^{\prime} \mathrm{N}, 6^{\circ} 58^{\prime} \mathrm{W}\right)$. The study site is a sand dune spit with gravel and calcareous shell deposits, which was selected as it supports one of the few existing populations of Glaucium flavum in south-western Spain. The physicochemical properties of the soil are given in Table 1. The climate is Mediterranean with an Atlantic influence (Marine Mediterranean Climate). Data for monthly rainfall and mean monthly temperature were obtained from the Huelva (Ronda Este) Meteorological Station located next to the study site (Fig. 1). During the experimental period, the climatic conditions were typical of the region: a summer drought occurred



Time, month

Fig. 1. Monthly rainfall $(\mathrm{mm})(\boldsymbol{\square})$ and mean monthly temperature $\left({ }^{\circ} \mathrm{C}\right)(\bullet)$ at the Huelva (Ronda Este) Meteorological Station from January to December 2007. from June to July, when practically no rain fell and mean monthly temperatures reached maximum values. Winter was relatively wet, and the lowest temperatures were reached in this period.

Ecophysiological measurements were always carried out on the same plants selected from the study site, and were taken on young rosette leaves of the same orientation relative to the light, to avoid effects of microclimatic variation. Measurements were taken from January to December 2007 with twelve sampling dates, one in the middle of each month, in order to study the photosynthetic performance and nutrient status of the plant in response to the strong seasonal variability of the Mediterranean climate.

\section{Gas Exchange}

Gas exchange measurements were taken monthly from the fully developed leaves of 10 plants randomly chosen in the field ( $n=20$, two measurements per plant), using an infrared gas analyzer in an open system (LI-6400, LI-COR Inc., Neb., USA). All measurements were taken at the same time of day, between 10 a.m. and 11 a.m., to eliminate any possible diurnal variation. Net photosynthetic rate (A), intercellular $\mathrm{CO}_{2}$ concentration $\left(\mathrm{C}_{\mathrm{i}}\right)$ and stomatal conductance of $\mathrm{CO}_{2}\left(\mathrm{G}_{\mathrm{s}}\right)$ were determined at ambient $\mathrm{CO}_{2}$ concentration of $365 \mu \mathrm{mol} \mathrm{mol}{ }^{-1}$, temperature of $20 / 25^{\circ} \mathrm{C}$, $50 \pm 5 \%$ relative humidity and photon flux density of $1000 \mu \mathrm{mol} \mathrm{m} \mathrm{m}^{-2} \mathrm{~s}^{-1} \mathrm{~A}, \mathrm{C}_{\mathrm{i}}$ and $\mathrm{G}_{\mathrm{s}}$ were calculated using the standard formulae of Von Caemmerer and Farquhar (1981).

\section{Leaf Water Content}

Leaf water content (LWC) of fully expanded rosette leaves from each plant ( $n=20$, two leaves per plant) was calculated every month as:

$$
\mathrm{LWC}=(F W-D W) / F W \times 100,
$$

where $F W$ is the fresh mass of the leaves, and $D W$ is the dry mass after oven-drying at $80^{\circ} \mathrm{C}$ for $48 \mathrm{~h}$ (Medrano and Flexas, 2004). Leaves were collected in the field, at the same time as gaseous exchange measurements were taken, and immediately transferred to the laboratory, where samples were processed.

\section{Chlorophyll Fluorescence and Photosynthetic Pigments}

Chlorophyll fluorescence was measured monthly in the field in the same 10 plants, in randomly chosen, fully expanded leaves $(n=20$, two measurements per plant) using a portable modulated fluorimeter (FMS-2, Hansatech Instrument Ltd., England). Light- and dark-adapted fluorescence parameters were measured at dawn (stable, $50 \mu \mathrm{mol} \mathrm{m}^{-2} \mathrm{~s}^{-1}$ ambient light) and at midday $\left(1600 \mu \mathrm{mol} \mathrm{m}^{-2} \mathrm{~s}^{-1}\right)$ according to the methodology used by Cambrollé et al. (2011a). The following parameters were calculated: maximum quantum efficiency of PSII photochemistry $\left(\mathrm{F}_{\mathrm{v}} / \mathrm{F}_{\mathrm{m}}\right)$, quantum effi- 
ciency of PSII (ФPSII), and non-photochemical quenching (NPQ).

In each season of the year, fully expanded rosette leaves from each plant ( $n=20$, two leaves per plant) were excised and immersed in liquid $\mathrm{N}_{2}$ for transfer to the laboratory. Photosynthetic pigments were extracted according to the methodology used by Cambrollé et al. (2011a). Concentrations of pigments (chlorophyll a, Chl $a$; chlorophyll b, Chl $b$; and carotenoid, $\mathrm{C} x+c$ ) were obtained by calculation, using the method of Lichtenthaler (1987).

\section{Nutrient Analysis}

Rosette leaf samples, randomly chosen from the population, were collected every two months from January to November 2007 and taken to the laboratory $(n=5)$. In addition, samples from the uppermost $20 \mathrm{~cm}$ of soil (corresponding to an average rooting depth of $G$. flavum) were taken in areas where vegetation was absent $(n=5)$. Leaves were carefully washed with distilled water before any further processing or analysis. The soil and washed leaf samples were then dried at $80^{\circ} \mathrm{C}$ for $48 \mathrm{~h}$ and ground. Dried soil samples were ground and homogenized by sieving through $2 \mathrm{~mm}^{2}$ nylon mesh in order to remove large stones and dead material. Plant samples $(0.5 \mathrm{~g} ; n=5)$ were digested with $6 \mathrm{~mL} \mathrm{HNO}_{3}, 0.5 \mathrm{~mL} \mathrm{HF}$ and $1 \mathrm{~mL} \mathrm{H}_{2} \mathrm{O}_{2}$, while soil samples were digested with $2 \mathrm{~mL} \mathrm{HNO}_{3}, 1 \mathrm{~mL} \mathrm{HF}$ and $5 \mathrm{~mL} \mathrm{H}_{2} \mathrm{O}_{2}$. P, S, K, $\mathrm{Ca}$ and $\mathrm{Mg}$ contents of all samples were then measured by inductively coupled plasma (ICP) spectroscopy (ARL-Fison 3410, USA). Total $\mathrm{N}$ concentrations were determined for undigested dry samples with an elemental analyzer (Leco CHNS-932, Spain).

\section{Statistical Analysis}

Statistical analysis was carried out using Statistica v. 6.0 (Statsoft Inc.). Pearson coefficients were calculated to assess correlation between different variables. Seasonal variations were analyzed using a one-way analysis of variance ( $F$-test). Significant test results were followed by Tukey tests for identification of important contrasts. Differences between measurements of fluorescence at dawn and midday were compared by the Student test ( $t$-test). Data were first tested for normality with the Kolmogorov-Smirnov test and for homogeneity of variance with the Brown-Forsythe test.

\section{RESULTS}

\section{Gas Exchange}

Net photosynthesis rate (A) showed a significant seasonal pattern, with the lowest values in January and July (ANOVA, $p<0.001$ ). This parameter progressively increased from the beginning of the year to reach an annual peak in April $(r=0.74, p<0.0001)$. A declined

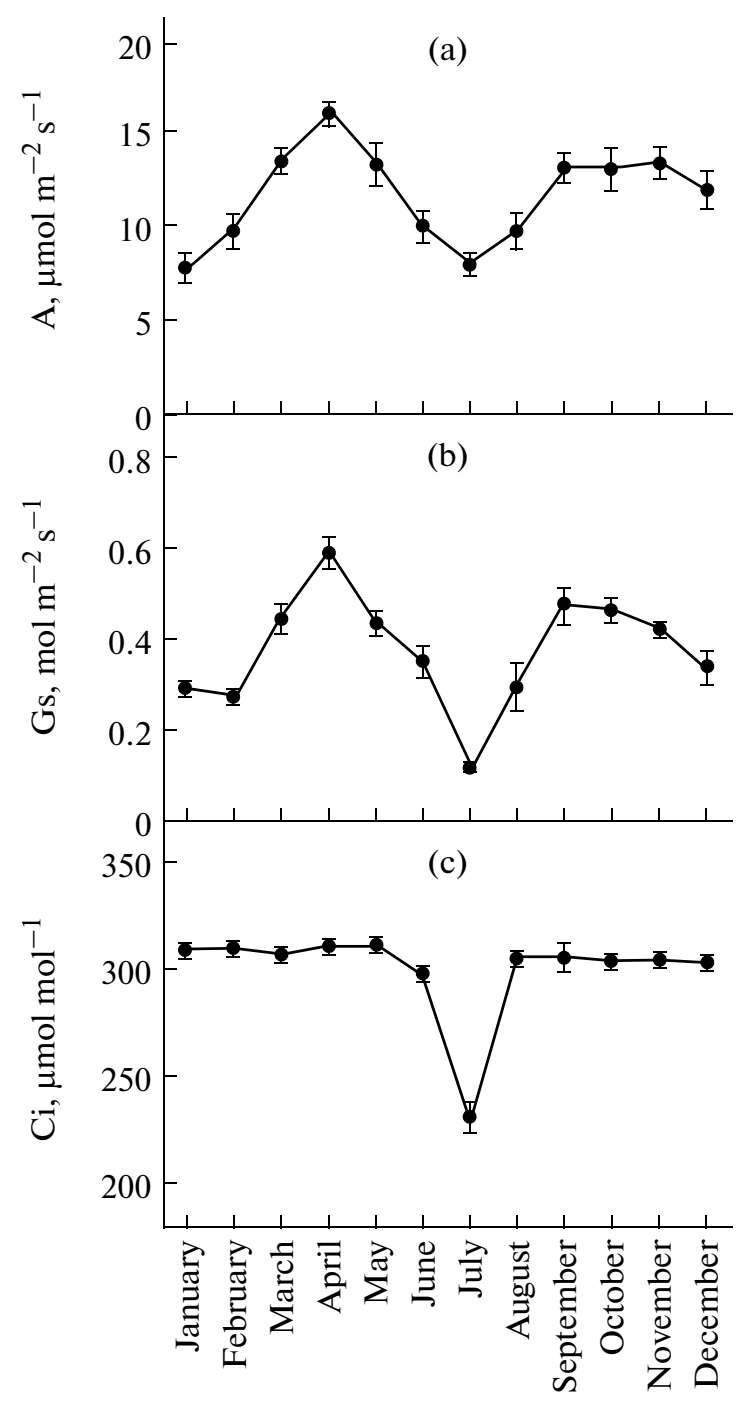

Time, month

Fig. 2. Net photosynthetic rate, A (A), stomatal conductance, $\mathrm{Gs}(\mathrm{B})$, and intercellular $\mathrm{CO}_{2}$ concentration, $\mathrm{C}_{\mathrm{i}}(\mathrm{C})$ in randomly selected, fully expanded leaves of Glaucium flavum throughout the study period. Values represent mean $\pm \mathrm{SE}, n=20$.

to about $50 \%$ from April to July and increased again in September, maintaining similar values until the end of the year (Fig. 2A). Stomatal conductance rate $\left(\mathrm{G}_{\mathrm{s}}\right)$ showed a trend similar to that of A. Intercellular $\mathrm{CO}_{2}$ concentration $\left(\mathrm{C}_{\mathrm{i}}\right)$ showed little differences throughout the year, but decreased in June reaching a minimum value in July (Fig. 2C).

\section{Leaf Water Content}

Leaf water content was almost constant in autumn and winter $(\sim 82 \%)$, and showed maximum values in April and September. LWC decreased slightly in June and July reaching a minimum value in August ( $10 \%$ lower than the maximum values) (Fig. 3). 


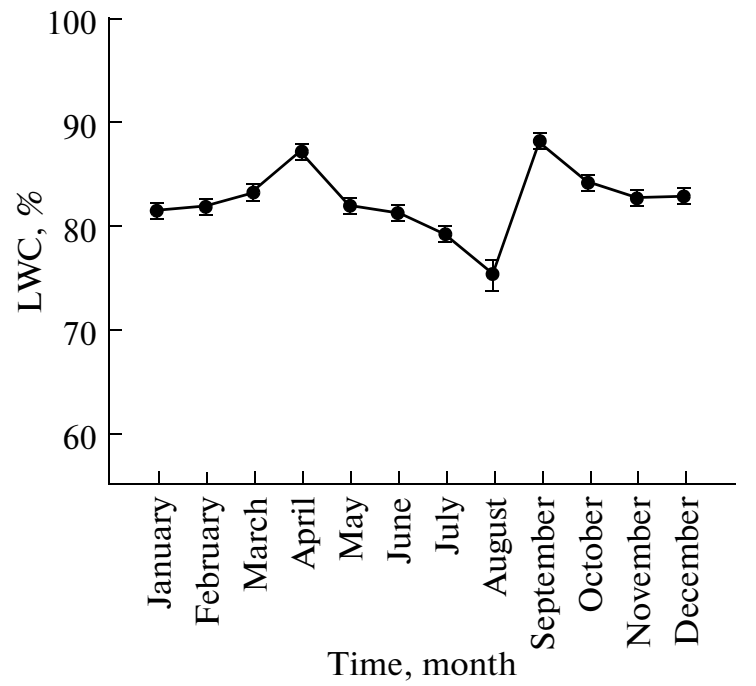

Fig. 3. Leaf water content of Glaucium flavum throughout the study period. Values represent mean $\pm \mathrm{SE}, n=20$.

\section{Chlorophyll Fluorescence and Photosynthetic Pigments}

The potential photochemical efficiency $\left(\mathrm{F}_{\mathrm{v}} / \mathrm{F}_{\mathrm{m}}\right)$ at midday showed maximum values in April and September and minimum values in January and February. However, these seasonal contrasts were not found to be significant (ANOVA, $p>0.05$ ). Seasonal variations of $\mathrm{F}_{\mathrm{v}} / \mathrm{F}_{\mathrm{m}}$ were significant at dawn, reaching minimum values in January and February (ANOVA, $p<0.01$ ). $\mathrm{F}_{\mathrm{v}} / \mathrm{F}_{\mathrm{m}}$ was lower at midday than at dawn ( $t$-test, $p<$ 0.001) (Fig. 4A). The reduction of dawn $F_{v} / F_{m}$ during winter months was the result of an increase in $\mathrm{F}_{0}$, while $\mathrm{F}_{\mathrm{m}}$ was maintained at a stable level (data not presented).

Quantum efficiency of PSII (ФPSII) at dawn was directly correlated with A $(r=0.70, p<0.05)$. Midday ФPSII showed no clear seasonal variations (ANOVA, $p>0.05$ ), with values remaining around 0.38 , and showed an annual peak in April and minimum values in January and February. ФPSII was always lower at midday ( $t$-test, $p<0.001$; Fig. 4B). Non-photochemical quenching (NPQ) at midday showed maximum values from January to April but decreased in May, maintaining similar values until the end of the year; dawn values showed no clear seasonal variations throughout the study period (Fig. 4C).

Pigment concentrations showed significant variations throughout the study period with maximum values during April and October and minimum values in July (ANOVA, $p<0.001$ in both cases). Chlorophyll $a+b$ showed values ranging between 5.02 and $3.02 \mu \mathrm{g} \mathrm{g}^{-1}$, while the measurement of carotenoids $\mathrm{C} x+c$, produced values of between 1.24 and $0.67 \mu \mathrm{g} \mathrm{g}^{-1}$ (Figs. 5A-5B).

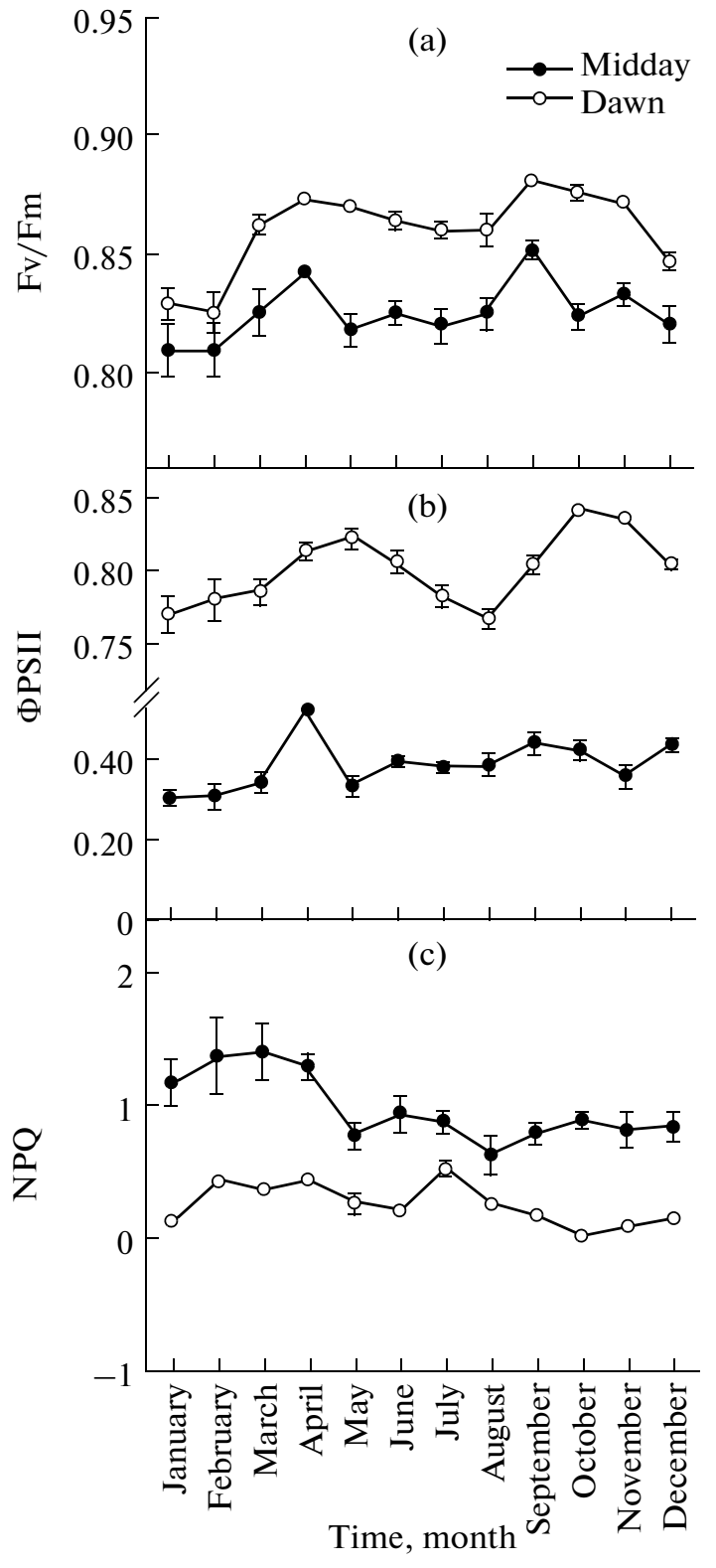

Fig. 4. Maximum quantum efficiency of PSII photochemistry, $F_{v} / F_{m}(A)$, quantum efficiency of PSII, ФPSII (B) and non-photochemical quenching, NPQ (C), at mid-day $(\bullet)$ and at dawn $(\bigcirc)$ in randomly selected, fully expanded leaves of Glaucium flavum throughout the study period. Values represent mean $\pm \mathrm{SE}, n=20$.

\section{Nutrient Analysis}

Soil N concentrations ranged from 0.04 to $0.12 \%$ (Fig. 6A). P, S and K concentrations showed no seasonal contrasts throughout the study period with values remaining around $0.25,0.32$ and $3.97 \mathrm{mg} / \mathrm{g}$, respectively (Figs. 6B-6D). There were significant differences in $\mathrm{Ca}$ and $\mathrm{Mg}$ concentrations between sampling dates (ANOVA, $p<0.001$ in both cases). Soil Ca and Mg concentrations ranged from 38.73 to $95.14 \mathrm{mg} / \mathrm{g}$ and from 0.51 to $1.67 \mathrm{mg} / \mathrm{g}$, respectively (Figs. 6E-6F). 
Leaf $\mathrm{N}$ and $\mathrm{S}$ concentrations showed significantly lower values in July than those observed throughout the rest of the year (ANOVA, $p<0.001$ in both cases), and showed maximum values in September and May, respectively (Figs. 6A, 6C). Minimum P concentrations were found in November and January but increased in March, maintaining similar values for the rest of the year (ANOVA; $p>0.05$; Fig. 6B). K concentrations showed maximum values in May and then decreased to minimum values in September (Fig. 6D). Ca concentration showed no clear seasonal variations during the year, with values ranging between 21.8 and $46.8 \mathrm{mg} / \mathrm{g}$ (Fig. 6E). In contrast, there was a marked increase in foliar $\mathrm{Mg}$ concentration from January to November $(r=0.72, p<0.0001$; Fig. 6F).

\section{DISCUSSION}

Throughout the study period, gas exchange and chlorophyll fluorescence parameters, as well as leaf water content, photosynthetic pigment and leaf nutrient concentrations varied markedly among seasons. Many studies on Mediterranean species have shown seasonal adjustments in these parameters as a consequence of the marked seasonality of the Mediterranean climate (e.g. Karavatas and Manetas, 1999; Gulías et al., 2009).

\section{Photosynthetic Performance and Water Relations}

The data show a seasonal pattern of strong depression of gas exchange and stomatal conductance during summer and winter, with maximum values reached during spring and autumn, the periods associated with highest water availability. This pattern suggests stomacontrolled gas exchange triggered by variations in water soil availability, a mechanism commonly found in Mediterranean vegetation (Chaves, 1991). Values of net photosynthesis and stomatal conductance were within the range of those reported by other authors in different species living in the Mediterranean region (e.g. Gratani, 1995; Llorens et al., 2003; Gulías et al., 2009).

The summer depression of net photosynthesis appeared to be due to a reduction in intercellular $\mathrm{CO}_{2}$ concentration $\left(\mathrm{C}_{\mathrm{i}}\right)$, which can be explained by the drastic decrease in $G_{s}$ in response to summer drought. The marked reduction in gas exchange rates concurrent with a lack of drastic decline in LWC during the early summer indicates that $G$. flavum behaves as a drought-avoiding species, with a high stomatal sensitivity to slight decreases in tissue water content (Levitt, 1980). This agrees with Davy et al. (2001) who suggested that stomatal regulation may be extremely efficient in this kind of coastal species. Our results showed that net photosynthesis rate was reduced in winter, reaching a minimum value in January, the coldest month of the year. The marked decline of stomatal conductance in the absence of important changes in

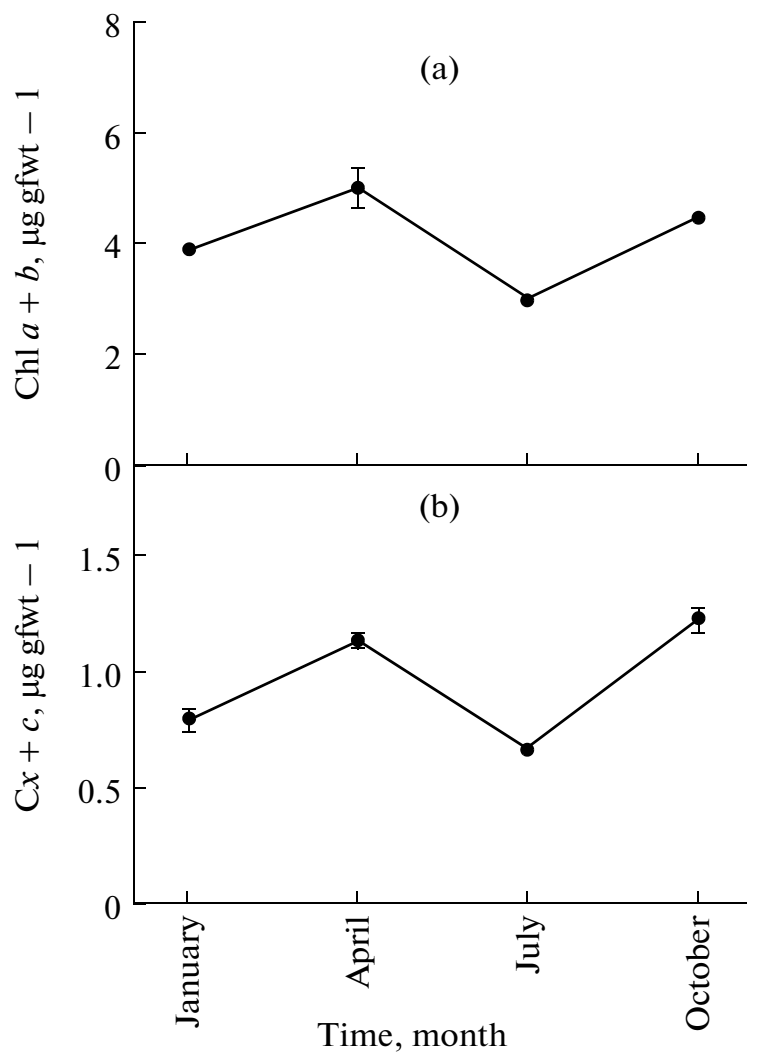

Fig. 5. Chlorophyll $a$ and $b(\mathrm{chl} a+b)$ (A), and carotenoid $(\mathrm{C} x+c)(\mathrm{B})$ concentrations in randomly selected, fully expanded leaves of Glaucium flavum in January, April, July and October. Values represent mean $\pm \mathrm{SE}, n=20$.

$\mathrm{C}_{\mathrm{i}}$, indicates that the reported reduction in photosynthetic activity during the cold season could be partially due to a winter reduction of demand for $\mathrm{C}$, as well as to effects on photosynthetic apparatus (Lambers et al., 1998). Under laboratory conditions, PSII electron transport and $\mathrm{CO}_{2}$ fixation can correlate very well (Genty et al., 1989). Although this correlation can break down under field conditions (Maxwell and Johnson, 2000), we found that the general pattern of seasonal variation in A was similar to that of dawn ФPSII. In winter, this parameter reached minimum values as a consequence of the increase in NPQ, which indicates that the plants dissipated light as heat, thus protecting the leaf from light-induced damage (Maxwell and Johnson, 2000).

Photoinhibition is caused by damage to photosynthetic components: the effect can be short-term and reversible (dynamic photoinhibition) or long-term and irreversible (chronic photoinhibition; Werner et al., 2002). During summer, both drought and excess light can affect plant carbon assimilation. However, $\mathrm{F}_{\mathrm{v}} / \mathrm{F}_{\mathrm{m}}$ remained close to the optimal values given by Björkman and Demmig (1987), even during the months with the most severe conditions in terms of light, temperature and water deficit, showing that 


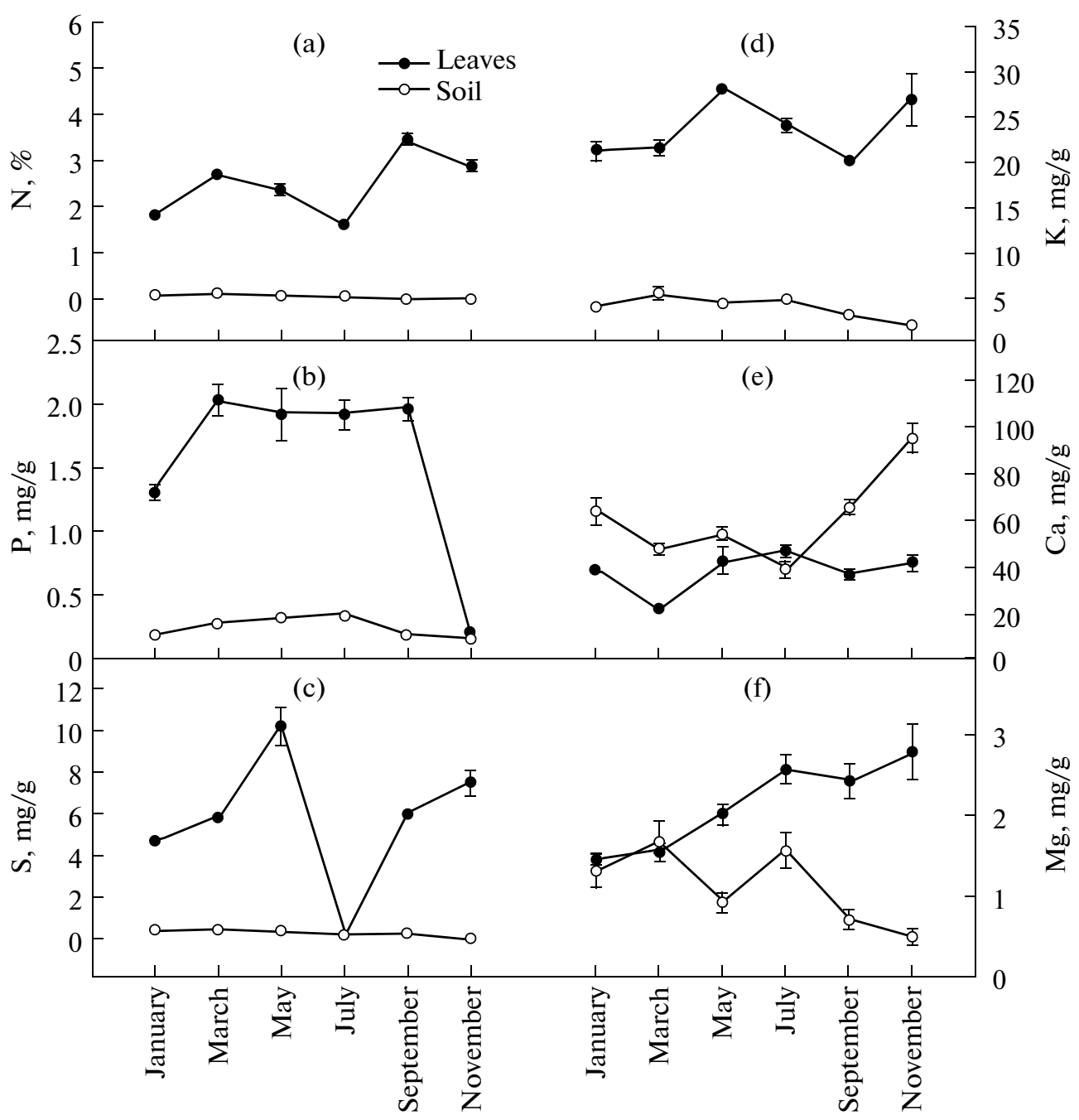

Time, month

Time, month

Fig. 6. Total nitrogen (A), total phosphorus (B), total sulphur (C), total potassium (D), total calcium (E) and total magnesium (F) concentrations for leaves of Glaucium flavum $(\bullet)$ and soil $(\bigcirc)$ throughout the study period. Values represent mean $\pm \mathrm{SE}, n=5$.

photoinhibition was not responsible for the summer depression of net photosynthesis. Our results indicate that drought must dominate over excess light as a limiting factor under summer conditions. Low temperatures affect plant survival by three processes: loss of metabolic activity (chilling stress) (Mc Kersie and Desker, 1994); ice formation within the tissues (freezing stress) (Guy, 1990); and the overexcitation of the photosynthetic apparatus (photochilling stress) (Wise and Naylor, 1987). Scott (1963) reported that frost has little effect on Glaucium flavum. Our data reflect that $\mathrm{F}_{\mathrm{v}} / \mathrm{F}_{\mathrm{m}}$ recovery from the midday decline in winter, when temperatures reached seasonal minimum values, thus indicating an accumulation of photodamage (Osmond, 1994). This decline of $F_{v} / F_{m}$, which was mainly caused by higher values of $F_{0}$, could be ascribed to the reduction in energy transfer from the collecting antennae of the PSII to the reaction centres, which may be related to the reported winter decline in chlo- rophyll $(\mathrm{Chl})$ contents. Similar decreases in Chl content have been found in many other species of the Mediterranean region (e.g. Ain-Lhout et al., 2004). Nonetheless, there is no evidence to affirm that photoinhibition is the likely cause of decreased photosynthesis during winter, since the $F_{v} / F_{m}$ values remained near the optimum 0.8 for unstressed plants during this season (Björkman and Demmig, 1987). Despite the reported decline in chlorophyll fluorescence parameters, our results suggest that the marked reduction in photosynthetic activity during the cold season may be mainly due to a loss of metabolic activity.

The high photosynthetic performance in spring may be associated with the optimal environmental conditions of temperature and humidity, which allow the plant to maintain high tissue water content and develop the structures to produce a large number of fruits. Despite the summer decline in gas exchange, our results concur with previous studies that report the 
ability of this species to withstand drought (Scott, 1963): net photosynthesis rate remained higher than $7 \mu \mathrm{mol} \mathrm{m} \mathrm{m}^{-2} \mathrm{~s}^{-1}$ and chlorophyll fluorescence parameters showed insignificant decreases during this season. In addition, the plant develops bracts in its flowering stems during the dry season. These structures showed a photosynthesis rate ranged between 3.08 and $5.58 \mu \mathrm{mol} \mathrm{CO} \mathrm{CO}_{2} \mathrm{~m}^{-2} \mathrm{~s}^{-1}$ during the summer months (data not showed), thus contributing to maintain the necessary carbon gain to support the developing of new flowers and fruits during the severe conditions of the Mediterranean summer. In autumn, G. flavum showed a high photosynthetic rate which allowed the plant to acquire and accumulate the resources necessary to withstand the winter conditions.

\section{Nutrient Status}

It is generally accepted that the transport of nutrients in plants by the transpiration flux is the most important mechanism for a large proportion of water and nutrient transport availability (Marschner, 1995). Despite the low nutrient status of the study site (see Mengel and Kirkby, 1982), G. flavum showed leaf concentrations within the average parameters reported for plants in general by Markert (1992), and showed no visible symptoms of nutrient deficiency in the field (J. Cambrollé, pers. obs.). This could be ascribed to the creation of a large flow of nutrients towards the rhizosphere and/or the possibility of an additional source of nutrients. It is known that species from infertile environments tend to be more proficient at nutrient retranslocation, compared to those from fertile environments (Aerts and Chapin, 2000).

Earlier studies have reported that leaf concentrations of mobile nutrients (e.g., N, P, K) normally show a decline over time, e.g., from spring to autumn (Maier and Chvyl, 2003). The results show a decrease in foliar $\mathrm{N}$ and $\mathrm{K}$ concentrations from spring to summer, which may be related to the translocation of these mobile minerals to different sink organs (e.g. flowers and fruits). Leaf sulphur concentration also showed important variation throughout the year, suggesting a high phloem mobility of this element in G. flavum. On the other hand, both plant tissue and soil concentrations of $\mathrm{Ca}$ exceed the average contents reported by Market (1992). This is likely to be a consequence of the quantity of shell fragments present in the soil, due to the marine origin of the study site (Borrego et al., 2000). The low phloem mobility of this element was reflected in the very slight variations in foliar Ca concentration recorded over the year. The increase in foliar $\mathrm{Mg}$ from the beginning of the year to November may reflect an accumulation effect, linked to leaf age, as a consequence of low levels of Mg mobility in the phloem. Phosphorus is an important factor limiting plant growth and may be in short supply in this kind of habitat (Packham et al., 2001). Our data showed that leaf $\mathrm{P}$ concentrations were lower than those consid- ered sufficient for optimal growth by Marshner (1995). In the soil of the study site, which shows a basic $\mathrm{pH}$ (see Table 1) and a high Ca content, phosphorus may be present as calcium phosphate (Kooijman et al., 1998). Therefore, $P$ availability may be limited because of the low solubility of calcium phosphates in alkaline conditions (Mengel and Kirkby, 1982). In this context, P uptake by G. flavum may be dependent on the ability of the plant to modify the rhizosphere surrounding the root surface (e.g. by excretion of organic components that reduce $\mathrm{pH}$ or by the secretion of phosphatase enzymes; Marschner, 1995). The marked reduction of foliar P in January and November may be partially ascribed to a reduction in the energy demand of the plant, as consequence of the loss of metabolic activity in the cold season.

\section{CONCLUSIONS}

Our study highlights the efficiency of the different physiological adaptations of this coastal species in coping with the strong seasonality of the Mediterranean climate. Our results suggest a high degree of stomatal control, which, along with the other morphological features previously described, allows this species to withstand the summer conditions by minimizing exposure to stress in its tissues. In our study, the marked decline in net photosynthesis during the winter seems to be mainly related to a loss of metabolic activity. Nonetheless, the potential photochemical efficiency of PSII showed minimum values during this season, indicating that low temperatures can produce negative effects within the photosynthetic apparatus of $G$. flavum. The low concentrations of foliar phosphorus, which may be related to the low availability of this element in the calcareous soils where the species usually grows, indicate that this macronutrient could be an important limiting factor for $G$. flavum in this kind of habitat.

\section{ACKNOWLEDGMENTS}

We are grateful to Mr. K. MacMillan for revision of the English version of the manuscript. We also thank the Spanish Ministry of Education (FPU programme, AP2007-04420) and the Junta de Andalucía (RMN224) for financial support, and the Directorate of the Odiel Marshes Natural Park for collaboration.

\section{REFERENCES}

Aerts, R. and Chapin, F.S., The mineral nutrition of wild plants revisited: A re-evaluation of processes and patterns, Adv. Ecol. Res., 2000, vol. 30, pp. 1-67.

Ain-Lhout, F., Diaz-Barradas, M.C., Zunzunegui, M., Rodríguez, H., García-Novo, F., and Vargas, M.A., Seasonal differences in photochemical efficiency and chlorophyll and carotenoid contents in six Mediterranean shrub species under field conditions, Photosynthetica, 2004, vol. 42, pp. 399-407. 
Björkman, O. and Demming, B., Photon yield of $\mathrm{O}_{2}$ evolution and chlorophyll fluorescence characteristics at $77 \mathrm{~K}$ among vascular plants of diverse origins, Planta, 1987, vol. 170, pp. 489-504.

Borrego, J., Morales, J.A. and Gil, N., Holocene facies architecture at the Odiel estuary fluvial domain (SW Spain), Geogaceta, 2000, vol. 27.

Cambrollé, J., Mateos-Narajo, E., Redondo-Gómez, S., Luque, T. and Figueroa, M.E., Growth, reproductive and photosynthetic responses to copper in the yellow-horned poppy, Glaucium flavum Crantz, Environ. Exp. Bot., 2011a, vol. 71, pp. 57-64.

Cambrollé, J., Redondo-Gómez, S., Mateos-Narajo, E., Luque, T. and Figueroa, M.E., Physiological responses to salinity in the yellow-horned poppy, Glaucium flavum, Plant Physiol. Biochem., 2011b, vol. 49, pp. 186-194.

Chaves, M. M., Effects of water deficits on carbon assimilation, J. Exp. Bot., 1991, vol. 42, pp. 1-16.

Davy, A.J., Willis, A.J. and Beerling, D.J., The plant environment: Aspects of the ecophysiology of shingle species, in Ecology and Geomorphology of Coastal Shingle, Westbury Acad. Sci. Publ., 2001, pp. 191-201.

Figueroa, M.E., Fernández-Baco, L., Luque, T. and Davy, A.J., Chlorophyll fluorescence, stress and survival in populations of Mediterranean grassland species, J. Veget. Sci., 1997, vol. 8, pp. 881-888.

Genty, B., Briantais, J.-M. and Baker, N.R., The relationship between quantum yield of photosynthetic electron transport and quenching of chlorophyll fluorescence, Biochim. Biophys. Acta, 1989, vol. 990, pp. 87-92.

Gratani, L., Structural and ecophysiological plasticity of some evergreen species of the Mediterranean maquis in response to climate, Photosynthetica, 1995, vol. 31, pp. 335-343.

Gulías, J., Cifre, J., Jonasson, S., Medrano, H. and Flexas, J., Seasonal and inter-annual variations of gas exchange in thirteen woody species along a climatic gradient in the Mediterranean island of Mallorca, Flora, 2009, vol. 204, pp. 169-181.

Guy, C.L., Cold acclimation and freezing stress tolerance: Role of protein metabolism, Annu. Rev. Plant Physiol. Plant Mol. Biol., 1990, vol. 41, pp. 187-223.

Karavatas, S. and Manetas, Y., Seasonal patterns of photosystem 2 photochemical efficiency in evergreen sclerophylls and drought semi-deciduous shrubs under Mediterranean field conditions, Photosynthetica, 1999, vol. 36, pp. 41-49.

Kintsurashvili, L.G. and Vachnadze, V.Y., Alkaloids of Glaucium corniculatum and G. flavum growing in Georgia, Chem. Nat. Compd., 2000, vol. 36, pp. 225-226.

Kooijman, A.M., Dopheide, J.C.R., Sevink, J., Takken, I., and Verstraten, J.M., Nutrient limitations and their implications on the effects of atmospheric deposition in coastal dunes; lime-poor and lime-rich sites in the Netherlands, J. Ecol., 1998, vol. 86, pp. 511-526.

Lambers, H., Chapin, F.S. III and Pons, T.L., Plant Physiological Ecology, New York: Springer, 1998.

Levitt, J., Responses of Plants to Environmental Stresses, NewYork: Academic, 1980.

Lichtenthaler, H.K., Chlorophylls and carotenoids: Pigments of photosynthetic biomembranes, Methods Enzymol., 1987, vol. 148, pp. 350-382.
Llorens, L., Peñuelas, J. and Filella, I., Diurnal and seasonal variations in the photosynthetic performance and water relations of two co-occurring Mediterranean shrubs, Erica multiflora and Globularia alypum, Physiol. Plant., 2003, vol. 118, pp. 84-95.

Maier, N.A. and Chvyl, W.L., Seasonal variation in nutrient status of Australian waxflowers, J. Plant Nutr., 2003, vol. 26, pp. 1873-1888.

Markert, B., Presence and significance of naturally occurring chemical elements of the periodic system in the plant organism and consequences for future investigations on inorganic environmental chemistry in ecosystems, Vegetatio, 1992, vol. 103, pp. 1-30.

Marschner, H., Mineral Nutrition of Higher Plants, London: Academic, 1995.

Maxwell, K. and Johnson, G.N., Chorophyll fluorescence: A practical guide, J. Exp. Bot., 2000, vol. 51, pp. 659-668.

Mc Kersie, D.D. and Desker, Y., Chilling stress, in Stress and stress coping in cultivated plants, Kluwer Academic Press, 1994, pp. 79-103.

Medrano, H. and Flexas, J., Relaciones hídricas de las plantas, in La Ecofisiología Vegetal., Una Ciencia de Síntesis, Thomson Editores, 2004, pp. 1141-1174.

Mengel, K. and Kirkby, A., Principles of Plant Nutrition, Worblaufen-Bern, Switzerland: International Potash Institute, 1982.

Osmond, C.B., What is photoinhibition? Some insights from comparisons of sun and shade plants, in Photoinhibition of Photosynthesis: From Molecular Mechanisms to the Field, Oxford: Bios Sci. Publ., 1994, pp. 1-24.

Packham, J.R. and Willis, A.J., Ecology of Dunes, Salt Marsh and Shingle, London: Chapman and Hall, 1997.

Pakham, J.R., Randall, R.E., Barnes, R.S.K. and Neal, A., Ecology and Geomorphology of Coastal Shingle, Otley: Westbury Acad. Sci. Publ., 2001.

Prieto, A., Campos, J.A., Garmendia, J., Loidi, J., Oreja, L., Patino, S. and Valencia, J., Flora amenazada presente en la Región Eurosiberiana de la comunidad autónoma del País Vasco, Naturalia Cantabricae, 2007, vol. 3, pp. 79-91.

Rappé, G., The distribution of some lesser known thalassochorous plant species along the Belgian coast, compared with their distribution in Western Europe, Biol. Jaarb., 1984, vol. 52, pp. 35-56.

Scott, G.A.M., Biological flora of the British Isles: Glaucium flavum Crantz, J. Ecol., 1963, vol. 51, pp. 743753.

Solås, H.F., Stabbetoro, O.E. and Nordal, I., The viability of a plant "on the edge": Glaucium flavum (Papaveraceae) in Norway, Nord. J. Bot., 2007, vol. 24, pp. 433-444.

Von Caemmerer, S. and Farquhar, G.D., Some relationships between the biochemistry of photosynthesis and the gas exchange of leaves, Planta, 1981, vol. 153, pp. 377-387. Werner, C., Correia, O. and Beyschlag, W., Characteristic patterns of chronic and dynamic photoinhibition of different functional groups in a Mediterranean ecosystem, Funct. Plant Biol., 2002, vol. 29, pp. 999-1011.

Wise, R.R. and Naylor, A.W., Chilling-enhanced photooxidation. Evidence for the role of singlet oxygen and superoxide in the breakdown of pigments and endogenous antioxidants, Plant Physiol., 1987, vol. 83, pp. 278-282. 